\title{
Syntactic Change and the Rise of Transitivity: The Case of the Polish and Ukrainian -no/-to Construction $^{1}$
}

\begin{abstract}
This paper analyzes the historical divergence of predicates marked with old passive neuter -no/-to in Polish and Ukrainian. It is argued that the locus of change leading to the rise of the transitivity property involved a rearrangement of morphologically-eroded voice morphology. Despite the surface similarity of the Polish and Ukrainian constructions, their divergent distribution in the modern languages indicates that grammaticalization of the old passive morpheme proceeded along different pathways, implicating the internal structure of $\nu \mathrm{P}$, and creating new accusative case-assigning possibilities.
\end{abstract}

\section{Keywords}

syntactic change, voice, passive, -no/-to construction, $v$-heads, accusative, natural force causers, Polish, Ukrainian

\section{Streszczenie}

Artykuł przedstawia analizę różnic w rozwoju form predykatów z wykładnikami strony biernej w rodzaju nijakim -no/-to w języku polskim i ukraińskim. Przybranie cech tranzytywnych przez te formy czasownikowe łączy się tu ze zmianami w obrębie morfologii strony gramatycznej w obu językach. Pomimo powierzchniowych podobieństw różnice w dystrybucji konstrukcji z czasownikami zakończonymi na -no/-to we współczesnym języku polskim i ukraińskim wskazują, że gramatykalizacja morfemu strony biernej przebiegła według różnych scenariuszy w obu językach, implikujących zróżnicowanie w strukturze frazy czasownikowej $v$ P, a także powstanie nowych możliwości przypisania cechy biernika.

${ }^{1}$ I gratefully acknowledge Ewa Willim, Ilja Seržant, and two anonymous reviewers for their close reading of the manuscript and many helpful comments. I also thank Bożena Cetnarowska and Bożena Rozwadowska for assistance with the Polish data; and Svitlana AntonyukYudina for assistance with the Ukrainian data. All errors of interpretation and analysis remain my own. 


\section{Słowa kluczowe}

zmiana składniowa, gramatyczna kategoria strony, pasywizacja, konstrukcja z -no/-to, wykładniki ośrodka frazowego $v$, biernik, nieosobowy sprawca czynności, język polski, język ukraiński

\section{Introduction}

The purpose of this paper is to explore the syntactic divergence of an impersonal predicate in Polish and Ukrainian, widely known as the -no/-to construction. Since the innovative structures in the two languages are based on the same moribund passive morpheme /-no/-to/, this analysis focuses on the arrangement of material in $v \mathrm{P}$, the functional domain responsible for hosting voice morphology, the projection of the external argument, the expression of causative semantics, and accusative case assignment.

In the modern languages, the -no/-to construction remains passive in Ukrainian only, so only the Ukrainian construction, for example, allows a passive $b y$-phrase. It is also the case that only the Ukrainian construction occurs with tense-marking auxiliaries. These properties are indicated in $(1):^{2}$

(1) a. Modern Polish ${ }^{3}$

( ${ }^{\star}$ Zostało)wsadzo-no cudzoziemca do więzienia

AUX-PST placed-PASs foreigner-ACC to prison

( ${ }^{*}$ przez szefa rządu).

through/by head-ACC of-government

'They placed a foreigner in prison.'

b. Modern Ukrainian

Inozemcja bulo posadže-no do v'jaznyci hlavoju urjadu

foreigner-ACC AUX-PST placed-PAss to prison head-INS of-state

'A foreigner was placed in prison by the head of state.'

Another feature of the Ukrainian construction, not shared in Polish, is the licit appearance of an oblique Instrument or Natural Force, as in $(2 b) ;{ }^{4}$ that is,

${ }^{2}$ An extensive literature is devoted to the -no/-to construction in Polish and Ukrainian. This includes the historical-typological literature (Parxomenko 1956; Petlyčnyj 1960; Shevelov 1963, 1969, 1979, 1989; Brajerski 1979; Dyła 1983; Pisarkowa 1984; Wieczorek 1987, 1994; Siewierska 1988; Adams 1998; Wiemer to appear), as well as theoretically-oriented work (Rozwadowska 1992; Maling 1993; Dziwirek 1994; Cetnarowska 2000; Maling and Sigurjónsdóttir 2002; Lavine 2005, 2013; Krzek 2013; Ruda 2014). The objective here is to provide an explicit description of how the constructions in the two languages diverged over time.

3 The unchanging word-final allomorphs, /-no/ and /-to/, are glossed as "PAss", indicating that they are passive forms etymologically. The precise status of these morphemes in the modern languages is the subject of this paper.

${ }^{4}$ The Natural Force arguments in (2a-b) are crucially not treated here as passive by-phrases. To be sure, the Natural Force causer is syncretic in Ukrainian with the instrumental-marked 
while (2b) is passive in form, there is no implicit Agent controlling the sun as an Instrument. The lack of human involvement rules out Polish (2a). ${ }^{5}$

(2) a. Modern Polish

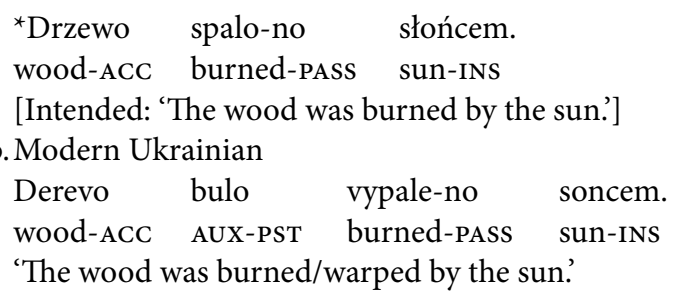

As the glosses in (1) indicate, the Polish construction is construed as active and (potentially) agentive, in which case accusative on the object is not necessarily anomalous, while the Ukrainian construction is either passive, in which case the underlying Agent can be expressed as an instrumental by-phrase, or can be formed on the basis of an entirely non-agentive predicate. In either case, the persistence of accusative case assignment in the absence of an overt subject, particularly as complement to a passive participle, is unexpected on standard assumptions of Passive and Case (see Woolford 2003 and Sigurðsson 2003 for relevant discussion).

In what follows, I show that /-no/-to/ marked a genuine, agreeing (neuter singular) passive in both languages prior to the $14^{\text {th }}$ century. We will see that the earliest examples of the Ukrainian impersonal passive in /-no/-to/ appeared to copy the surface syntax of the Polish construction: the passive morphology occurs with accusative on the direct object; there is no tense-marking auxiliary; and there is no passive by-phrase. We will have reason to claim, however, that Ukrainian was "unfaithful" to the underlying syntactic structure of the Polish construction. Section 2 details the morphological erosion of the neuter singular form $(/-\mathrm{o} /)$ that served as a trigger for the grammaticalization described in Section 3. Section 4 offers some concluding remarks on the source of transitivity (i.e. the accusative case-assigning property) and the diachronic processes involved in the innovative structures analyzed here.

passive by-phrase. The passive by-phrase in Polish is marked by the preposition przez 'through' + accusative. An anonymous reviewer notes that the example in (2a) is possible on the improbable reading in which an unpronounced human actor manipulates the sun. This, of course, is not the intended reading for $(2 \mathrm{a})$.

${ }^{5}$ Legate 2014 treats the Ukrainain construction in (2b), with a Natural Force causer, as passive, on a theory in which all Initiators (Agents, Instruments, Natural Force) receive an identical treatment as generated in Spec,VoiceP (subject position). The fact that Polish distinguishes between human actors and Natural Forces, admitting only the former in the -no/-to construction (cf. (2a)), provides evidence against Legate's all-inclusive Initiator. 


\section{The trigger: morphological reduction}

\subsection{Morphological change and reanalysis}

Syntactic structures depend to some extent on morphological properties, such as agreement and case markers. It follows that change in morphology may result in new syntactic arrangements, as novel structures are assigned to existing surface strings (reanalysis). Lightfoot (1979) notes that small changes in morphology complicate a grammar, leading to "therapeutic" changes that remove this complication. Consider the Old Polish example in (3):

(3) Old Polish

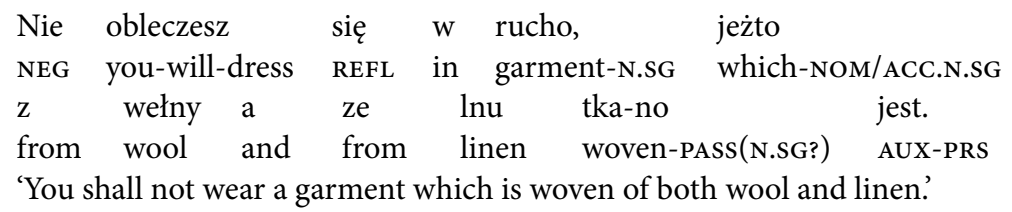

(Oesterreicher 1926: 55)

The relative pronoun jeżto is syncretic between nominative and accusative. On the analysis that tkano 'woven' is passive and agreeing (as neuter singular), that is, the more conservative form, then the relative pronoun is nominative. Alternatively, on the innovative analysis in which tkano is a new fixed form that patterns with accusative objects, then the relative pronoun must be accusative. The presence of the auxiliary in (3), as we will see, suggests the nominative analysis, while reanalysis of the old passive morpheme, giving an accusative object, involved the following cluster of changes: loss of the auxiliary, an active interpretation, and a ban on the passive by-phrase. Reanalysis creates a representation that is compatible with these changes, such that they are no longer interpreted as exceptions by the speaker. We now turn to the morphological irregularity that set the stage for the eventual emergence of the new impersonal transitive construction.

\subsection{The basis of reanalysis: /-o/ and the nominal declension of participles}

This section chronicles the morphological isolation of the erstwhile neuter singular marker /-o/ of the -no/-to construction. The Common Slavic participle (and adjective) exhibited two distinct declensions: a "short form" nominal declension and a "long form" pronominal declension. The latter was formed by adding the Common Slavic demonstrative pronoun to the nominal form. The initial distinction between the two declensions involved definiteness: the demonstrative pronoun in the pronominal declension functioned like a postposed definite article. Later, participles of the nominal declension were 
restricted to predicative use, such that the distinction between the nominal and pronominal declensions came to be defined positionally, rather than semantically (see Sprinčak 1960: 112-117 and Klemensiewicz et al. 1965: 323326; see Bailyn 1998 for related discussion).

The nominal declension was particularly susceptible to reduction in those languages in which the pronominal declension underwent some form of contraction or truncation, resulting in monosyllabic pronominal endings (in the nominative), which no longer contrasted as neatly with the endings of the initial nominal declension. It is precisely Polish and Ukrainian (and, e.g., not Russian or Belarusian) that saw this reduction, with the result that in these languages the contracted participles based on the initial pronominal declension now came to be used in the predicative position, further isolating the nominal forms (see Brajerski 1979 for Polish and Shevelov 1979 for Ukrainian).

The paradigm for the participial declension of nominal versus pronominal forms is given in Table 1. Common Slavic forms are given for reference, since the missing Polish and Ukrainian forms of the nominal declension were essentially those of Common Slavic before they were replaced by the contracted pronominal forms (contracted pronominal forms are in bold). Russian and Belarusian forms are given for comparison, to show that the nominal forms were not replaced precisely in those languages whose pronominal forms were not reduced.

Table 1. Paradigm of the nominal and pronominal declension of participles (nominative singular)

\begin{tabular}{|l|c|c|c|c|c|c|}
\hline \multirow{2}{*}{} & \multicolumn{3}{|c|}{ Nominal } & \multicolumn{3}{c|}{ Pronominal } \\
\cline { 2 - 7 } & $\mathrm{M}$ & $\mathrm{N}$ & $\mathrm{F}$ & $\mathrm{M}$ & $\mathrm{N}$ & $\mathrm{F}$ \\
\hline Late Common Slavic & $-\varnothing$ & $-\mathrm{o}$ & $-\mathrm{a}$ & $-\mathrm{yji}$ & - oje & -aja \\
\hline Polish & - & - & - & $-\mathbf{y}$ & $-\mathbf{e}$ & -a \\
\hline Ukrainian & - & - & - & - yj & $-\mathbf{e}$ & -a \\
\hline Russian & $-\varnothing$ & $-\mathrm{o}$ & $-\mathrm{a}$ & - oj & - ojo & -aja \\
\hline Belarusian & $-\varnothing$ & $-\mathrm{o}^{6}$ & $-\mathrm{a}$ & $-\mathrm{y}$ & - oe & -aja \\
\hline
\end{tabular}

The Common Slavic pronominal neuter singular form /-oje/ contracted in Polish and Ukrainian to /-e/ (with various irrelevant intermediate stages). The masculine nominal form, realized as a null suffix, was replaced in Polish and Ukrainian with the pronominal form /-y/ and the feminine forms - both nominal and pronominal - were now indistinguishable after the old pronominal form /-aja/ was contracted to /-a/. The crucial development for our purposes is

${ }^{6}$ Due to Belarusian "akan'e" (and its orthographic representation), neuter /-o/ is pronounced (and spelled) [a] in all unstressed positions. 
that the initial nominal form for the neuter singular, /-o/, now became isolated in its paradigm as the sole remaining member. This old neuter marker was clearly on a path to complete obsolescence had it not been assigned the new function of marking the new transitive construction. The loss of paradigmatic /-o/ was a strictly phonological development, believed to have been completed by the beginning of the $17^{\text {th }}$ century (Oesterreicher 1926: 57; Bevzenko 1960: 194; Brajerski 1979: 85; Shevelov 1979: 114-115). Shevelov (1969) and Brajerski (1979) argue that the impersonal transitive passive construction did not exist prior to the $14^{\text {th }}$ century; it was known neither in Old Church Slavonic nor in the earliest Polish and East Slavic documents (Shevelov 1969).

Prior to /-o/ falling into disuse as a marker of the neuter singular of participles, we can assume an intermediate stage in which a passive /-no/-to/ affix appeared as an agreeing form with an auxiliary and a raised nominative subject; and a non-agreeing impersonal construction with an accusative object (recall the attested ambiguous example in (3)). The point of reanalysis is schematized in the hypothetical Polish examples in (4). Note that the surface form of the participle is unchanged, though the gloss indicates two different interpretations of the word-final morphology. In constructing the examples in (4), I follow the observation dating back to Oesterricher 1926 that the accusative object came to be used productively only after the auxiliary's disappearance.

(4) Polish (hypothetical) ${ }^{7}$
a. Old Polish (pre-14 ${ }^{\text {th }}$ cent.): Canonical Passive
Okno $\quad$ (było) zamknię-to.
window-NOM.N.sG AUX-PST closed-N.SG
'The window was closed.'
b. Modern Polish (post-17 ${ }^{\text {th }}$ cent.): Active Impersonal
$\begin{array}{lll}\text { Okno } & \left({ }^{*} \text { było }\right) & \text { zamknię-to. } \\ \text { window-ACC } & \text { AUX-PST } & \text { closed-PASs }\end{array}$
They closed the window.

To anticipate the discussion to follow in Section 3, I will take the complementarity of accusative marking and overt auxiliaries in the Polish impersonal to indicate that the old neuter singular passive marker/-no/-to/ now itself heads Tense (it is a Tense marker in the modern language), thereby preventing the appearance of auxiliaries in the same position. ${ }^{8}$ We will see that the same analysis does not hold for Ukrainian, where tense-marking auxiliaries and accusative

\footnotetext{
${ }^{7}$ Note that prefixing an asterisk to parentheses indicates that the parenthesized material is obligatory (4a). Alternatively, an asterisk placed inside parentheses indicates that the parenthesized material is ungrammatical (4b).

${ }^{8}$ See Lavine 2005 for an earlier formulation of this idea. To be sure, /-no/-to/ prevents the appearance of tense-marking auxiliaries only (byt- ${ }_{\mathrm{PST}}$ zostat- $_{{ }_{\mathrm{PST}}}$ jest $_{\mathrm{PRES}}$, będzie ${ }_{\mathrm{FUT}}$, zostanie $_{\mathrm{FUT}}$ ). While /-no/-to/ is treated here as a Tense head, realizing the feature [+past], it is also affixal and,
} 
co-occur. In the case of Ukrainian, an analysis is developed that treats /-no/to/ as heading a variety of $v$, the functional layer above lexical VP. The innovation in Ukrainian will have to do with the internal structure of $v \mathrm{P}$, rather than a categorial change, as in Polish. In both cases, reanalysis of the /-no/-to/ suffix is treated as a kind of "therapy" on the grammar (in the sense of Lightfoot 1979) to make regular the appearance of accusative on the complement of an (etymological) passive participle. The idea is that Polish and Ukrainian adjusted the underlying syntax to accommodate this new case possibility.

\section{Two pathways of change}

In the following discussion, I adopt an approach to grammaticalization which involves the reanalysis of purely functional material, that is, reanalysis from one functional position to another or a change in the feature composition of a functional head (Lightfoot 1979, 1991; Roberts and Roussou 2003). So reanalysis of already existing functional material should, strictly speaking, concern only the category of a functional head or its shape (i.e., whether the change leads to a more articulated structure). The principal question of this section is how reanalysis in the voice system gave rise to a productive impersonal structure in the modern languages with accusative marking on the object. We are concerned, then, with the rise of transitive impersonals.

I assume that the standard case of passivization minimally involves the introduction of a passive morpheme in a Voice head above V, with the effect of existentially binding the external argument. All matters of case-marking and NP-movement follow from independent principles. Now since the Voice head (a variety of $v$ ) is also responsible for accusative on the V's complement, the merger of voice morphology is typically taken to suppress $v$ 's function as an accusative case assigner. That is, the same $v$-head is taken to be responsible for the projection of an external argument (that is, active versus passive voice) and the licensing of accusative case (Chomsky 1995; Kratzer 1996). This gives a structural account of Burzio's Generalization - that accusative case cannot be assigned internally (to the object NP) unless a theta role is assigned externally (to the subject NP). Thus, a passive (typically) does not occur with accusative on the object, according to this stipulation, because Voice, when headed by passive morphology, does not project a subject.

as such, would be predicted to combine with modal auxiliaries, such as musieć 'must', which is exactly the case, as in (i):

(i) Żeby weterynarze mogli przebadać misie, musia-no podać środki nasenne. so-that veterinarians could examine bears must-pass give medicine sleeping 'So that the veterinarians could examine the bears, they had to give (them) sleeping pills.' (Gazeta.pl; 18.06.2012) 
Much recent work has argued, however, that since the external thematic property and the internal case property are not linked conceptually, they should, in principle, be represented by two distinct functional heads (Bowers 2002; Collins 2005; Pylkkänen 2008; Lavine 2010a, 2013). Pylkkänen (2008) argues that languages parameterize this possibility. She distinguishes a higher VoiceP as the projection that introduces the external argument from a lower CauseP which introduces causative semantics. I show that Cause, when active, functions as an accusative case assigner ("probe"), regardless of the setting for Voice. According to Pykkänen's (2008) "voice-bundling parameter," languages either bundle these two properties of Voice and Cause, or project both as distinct heads. When the two heads are bundled, passive Voice suppresses accusative licensing on the object, giving the effect of Burzio's Generalization, as described earlier. ${ }^{9}$ As unbundled, distinct heads, the transitivity property is structurally distinct from the argument-projecting property, which makes possible the assignment of accusative by Cause, regardless of the setting for Voice. This outlines the analysis for the Ukrainian construction. By hypothesis, this is one of only two ways in which accusative co-occurs with passive morphology. The other way is instantiated in Polish: accusative and passive morphology co-occur, but the passive morphology is reanalyzed as a property of Tense; it is merged directly in $\mathrm{T}$ and, it follows, is not voice-altering. ${ }^{10}$ We will have reason to believe that $v$ in the Polish construction is bundled, as in (6). The structure of $v$ in the Ukrainian impersonal passive is necessarily unbundled, as in (5). The arrow from Voice to its specifier indicates its argumentprojecting property, namely projection of an external argument (ea), either implicit (Ukrainian) or fully-thematic (Polish). ${ }^{11}$ Recall that $v$, either as a distinct Cause head, as in (5), or as a bundled Voice head, as in (6), is the accusative probe. In the event of a bundled $v$, only active $v$ (and not passive $v$ ) assigns accusative.

9 This is the case in English, in which "the causative relation and the external $\theta$-role are 'packaged' ... into one syntactic head” (Pylkkänen 2008: 100).

${ }_{10}$ Recall that I am treating the Polish /-no/-to/ morpheme as frozen, not subject to further analysis. Ruda (2014: 220-224) treats /-n/-t/ as a separate morpheme, heading an "impersonal active Voice" head ( Voice $_{n / t}$ ), dedicated to the function of the -no/-to construction, namely projecting a [human] null " $n \mathrm{P}$ " external argument. What our analyses share is that/-no/-to/ does not occupy the head of passive Voice. I leave open the question of whether Polish requires a second active Voice head for this single purpose.

${ }_{11}$ The external argument in Polish need not be agentive. Experiencer arguments serve equally well as the understood subject of Polish -no/-to (see Rozwadowska 1992), as well as holders of states. For Kratzer (1996: 122-123), the theta role of the external argument is determined by the Aktionsart of the VP (e.g., accomplishment, activity, state...) with which Voice combines. For example, if the VP is stative, the external argument is interpreted as the holder of the state. 
(5) Split- $v$

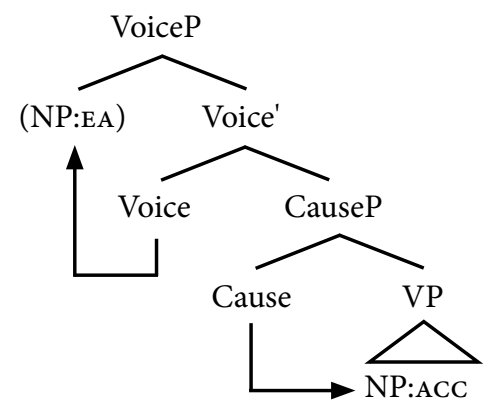

(6) "Bundled $v$ "

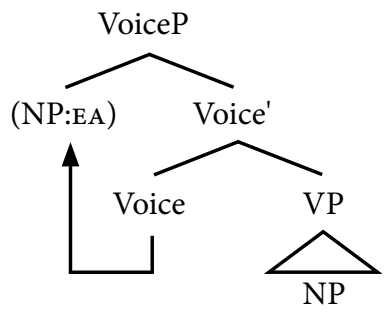

Key facts in support of these structures are drawn from the distribution of the /-no/-to/ construction in the two languages, discussed in Sections 3.1-3.4. The leading idea is that in the initial construction in Polish, the neuter object, which, recall from (4), was syncretic for nominative and accusative, gave rise to an ambiguous structure, with the further "exceptional" properties of eventually lacking a tense-marking auxiliary, occurring with non-paradigmatic/-o/, and, ultimately, receiving an active interpretation with a null subject. (4b) is repeated below as (7), adjusted for modern Polish (no auxiliary) and with the modern Polish sentential gloss as active:

(7) Modern Polish

Okno zamknię-to.

window-ACC closed-pass

'They closed the window.'

In contrast, the Ukrainian variant of (7), given in (8), is interpreted either as passive (e.g., with an optional $b y$-phrase) or as controlled by a Natural Force, and appears grammatically with a tense-marking auxiliary. The Ukrainian construction in (8) shares with its Polish counterpart only the original template of the old predicate-final /-no/-to/ morphology and its occurrence with accusative on the object.

(8) Modern Ukrainian

\begin{tabular}{|c|c|c|c|c|}
\hline $\begin{array}{l}\text { Vikno } \\
\text { window-ACC }\end{array}$ & $\begin{array}{l}\text { bulo } \\
\text { AUX-PST }\end{array}$ & $\begin{array}{l}\text { začyneno } \\
\text { closed-PASs }\end{array}$ & $\begin{array}{l}\text { (kymos') } \\
\text { someone-INS }\end{array}$ & $\begin{array}{l}\text { / (xolodnym } \\
\text { cold }\end{array}$ \\
\hline
\end{tabular}

We now turn to the different pathways of grammaticalization taken in the two languages, each a solution to the surface ambiguity described above. 


\subsection{Polish: Categorial Change}

In both Polish and Ukrainian, /-no/-to/ is now a fixed, unchanging form, no longer part of a productive paradigm. The question for each language is whether /-no/-to/ remains passive syntactically - i.e., whether it is voice-altering - or passive in form only. If the latter, as in the Polish construction, then the question arises as to where exactly /-no/-to/ is merged in the structure, and how best to describe its new function. We have already reviewed several aspects of the Polish construction which militate against merging /-no/-to/ under a Voice head. The most striking property, of course, is the appearance of accusative on the object complement of an apparent passive-participial predicate. However, the appearance of accusative is consistent with the active interpretation of the construction, as is the corresponding ban on the passive by-phrase, which is standardly treated as a syntactic reflex of an implicit external argument (see, e.g., Collins 2005; Bruening 2013). Note that while an external argument is syntactically projected, it is realized as a null, PRO-ARB argument. ${ }^{12}$ The analysis of the Polish construction as external-argument projecting predicts that it should not occur with unaccusatives, which I argue is the case. Another striking property of the Polish construction is its non-occurrence with tense-marking auxiliaries (though as pointed out by an anonymous reviewer, this is quite expected for Polish active sentences). These properties are now taken up in turn and given a unified analysis having to do with a basic change in the passive morpheme's syntactic category.

\subsection{Polish: Active Voice}

On the analysis of the Polish impersonal as active, we would not expect the passiveparticipial morpheme (strictly speaking, /-n/-t/) to be generated under the Voice head in (6). Passive Voice gives rise to a non-thematic (implicit) subject that triggers the appearance of the adjunct by-phrase, which is ungrammatical in the Polish construction. The example in (1a) is repeated below in (9a); the canonical, agreeing passive counterpart, with the licit by-phrase, is given for comparison in (9b).

(9) Polish

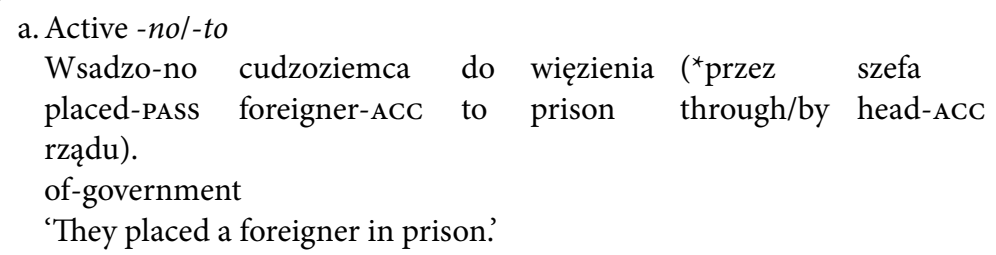

12 PRO-ARB refers to a sentient, human subject, arbitrary in reference (see Dyła 1983; Rozwadowska 1992; Maling 1993; and Dziwirek 1994, among others, for details). In point of fact, subjects of Experiencer and Perception verbs also occur in the Polish construction, in addition to Agents (see Rozwadowska 1992: 63-64; Kibort 2008; Ruda 2014: 207). 


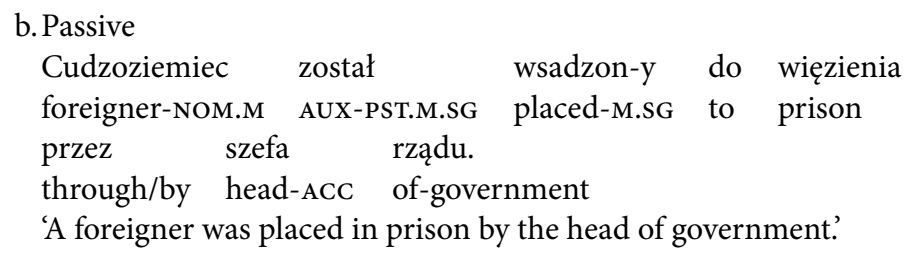

The presence of a null, fully-thematic Agent in subject position explains the illicit by-phrase in the impersonal construction. Now note that if Voice is indeed active, the null subject should exhibit subject properties, such as binding and control. The successful cases of binding and control in (10-11) are contrasted with cognate (and near cognate) expressions in Ukrainian (12-13) in order to tease apart the effect of a genuine agentive (though null) subject in the former versus the implicit subject of a passive in the latter. ${ }^{13}$ While such implicit subject effects (including control) are widely held to be robust in canonical passives (Baker et al. 1989; Collins 2005), in point of fact, they fail precisely in these contexts in Ukrainian (12-13), thereby indicating a difference in the status of the underlying subject in the two languages.

(10) Polish: Binding of Anaphor

Bi-to $_{\mathrm{i}} \quad$ strażników $_{\mathrm{j}} \quad$ swoimi $_{\mathrm{i} / *_{\mathrm{j}}} \quad\left(\mathrm{ich}_{\mathrm{x}_{\mathrm{i} / \mathrm{j}}}\right) \quad$ łańcuchami.

beaten-PASs guards-ACC REFL-INS.PL their chains-INS

'They $\mathrm{i}_{\mathrm{i}}$ beat the guards $\mathrm{j}_{\mathrm{j}}$ with their $\mathrm{i}_{\mathrm{i} /{ }_{\mathrm{j}}}$ chains.' (Kibort 2001)

(11) Polish: Control of Adverbial Gerund (GER)

Wracając do domu, śpiewa-no piosenki.

returning-GER to home sung-PAss songs-ACC

'They sang songs, returning home.' (Maling 1993)

(12) Ukrainian: Binding of Anaphor
Storoživ $_{j}$ bulo poby-to
guards-ACC AUX-PST beaten-PASS REFL-INS.PL their-INS.PL
lancjuhamy.
chains-INS.PL
'Guards ${ }_{\mathrm{j}}$ were beateni with their $\mathrm{x}_{\mathrm{x}_{\mathrm{i} / \mathrm{j}}}$ chains.'
(13) Ukrainian: Control of Adverbial Gerund (GER)

$\begin{array}{lllll}\text { *Povernuvšys' } & \text { dodomu, } & \text { hroši } & \text { bulo } & \text { znajde-no } \\ \text { having-returned-GER } & \text { to-home } & \text { money-ACC } & \text { AUX-PST } & \text { found-PAss }\end{array}$

In the Polish examples in (10-11), the anaphor and implied subject of the adverbial gerund are controlled (bound) by the subject of the "impersonal predicate" (now raising doubt as to the truly impersonal status of the construction).

${ }^{13}$ Recall the analysis for the Ukrainian construction, which treats the examples in (12-13) as genuine passives. 
In Ukrainian (12), the reading in which the implied subject of pobyto, that is, the one who did the beating, is coreferential with the possessor of the Instrument is unavailable. The underlying subject of the beating event is no longer syntactically active in its higher position - it does not occupy the specifier of a $v$-projection. Likewise, in (13), the only available reading is one in which it is the money that returned, rather than the one who found the money (that is, rather than the underlying subject argument of znajdeno 'found'). The crucial observation here is that while/-no/-to/ affixation suppresses the projection of the subject argument in Ukrainian - that is, it is voice-altering - the same morpheme has no such effect on the projection of a subject in Polish. This is precisely the kind of evidence that favors not treating /-no/-to/ as merged in a Voice head in Polish. ${ }^{14,15}$

Now we turn to the question of whether the Polish construction is necessarily argument-projecting. That is, must the Polish construction necessarily occur with a subject in the specifier of Voice. Active Voice has the principal function of projecting the predicate's subject (its external argument) in its specifier; Cause does not project an argument of its own - a predicate is identified as causative either by virtue of the presence of causative morphology heading Cause or by association with an internal argument with causative semantics (see Section 3.4). Whether appearing as a discrete syntactic head or bundled with active Voice, Cause is the source of accusative on the object NP. The question of whether Voice in the Polish construction is necessarily argument-projecting goes to the core of how we are to understand its feature content in the modern language, particularly whether it is still headed by voice morphology, such that there is some identifiable effect on argument alignment or case possibilities.

If Voice in the Polish construction is necessarily argument-projecting, as argued here, then it should not occur with unaccusative verbs, since they lack the external argument that Voice projects. The question is raised here since it has been argued that the Polish impersonal does not necessarily occur with a genuine subject and, indeed, can therefore be formed on the basis of unaccusative verbs (Maling 1993; Maling and Sigurjónsdóttir 2002; and, most recently, Ruda

${ }^{14}$ Unless, of course, we stipulate, following Ruda 2014, that /-n/-t/ itself heads a special impersonal active Voice.

${ }^{15}$ Notice that the implicit subject of the canonical, agreeing passive in Polish, as in (i), is also unable to control the implied subject of adverbial gerunds, thus patterning with the Ukrainian impersonal construction:

(i) Polish Passive

\begin{tabular}{|c|c|c|c|c|c|c|}
\hline${ }^{\star} \mathrm{Ta}$ & książka & była & czytan-a & (przez & Janka) & siedząc \\
\hline przy & $\begin{array}{l}\text { kominku. } \\
\text { fireplace }\end{array}$ & $A \cup X-F . S G$ & Iedal-r.s & IIIougn/ oy & Jane-ACC & SIIIIII-GER \\
\hline
\end{tabular}


2014). Note that apparent unaccusatives do occur, but only so long as they are atelic or interpreted as iterative (Rozwadowska 1992; Cetnarowska 2000):

(14) Polish Active Impersonal: Atelic
a. Umiera-no tam tysiacami
died-PAss there thousands:INST on typhus
'People died there in the thousands from typhus.'
(Śpiewak and Szymańska 1997: 150)
b. Bywa-no w teatrze raz na miesiąc. been-PASs in theater once per month 'People had been to the theater once a month.'

Meanwhile, note that telic unaccusatives are ruled out:

(15) Polish Active Impersonal: Telic
a. ${ }^{\star}$ Umar-to $\mathrm{z} \quad$ głodu.
died-Pass from hunger (Cetnarowska 2000: 90)
b. ${ }^{\star}$ By-to poniżanymi.
been-PASs humiliated:INST (Cetnarowska 2000: 84)

On the widely held view that unaccusatives are best defined in Aspectual terms, namely, as those intransitives that are telic (Borer 1994, 2005; Arad 1998; van Hout 2000, 2004), it follows that the examples in (14) do not argue against Voice as argument-projecting in the Polish construction if only the telic oneplace predicates in (15) are genuinely unaccusative. ${ }^{16}$ It follows that as an active Voice construction, the Polish impersonal fails in the absence of its argumentprojecting (PRO-ARB) property.

To summarize, we have considered in this section whether the erstwhile passive morpheme /-no/-to/ might still occupy a position affecting argument and case realization (Voice) in the modern language, as we assume it must have prior to the reanalysis of the morpheme, described in Section 2. While no single fact concerning the modern distribution of the Polish impersonal should be taken as definitive as to the status of /-no/-to/, the combination of facts presented, namely the ban on passive by-phrases, the robust binding and control properties, and the non-occurrence with unaccusatives, argues strongly in favor of the presence of an active Voice head in the construction. We now consider whether there is any evidence for /-no/-to/ having migrated to a different position in the structure. This is precisely the categorial change of the old passive morpheme alluded to earlier for the case of Polish.

${ }^{16}$ As Cetnarowska (2000: 89) notes, "[t]he use of the iterative/habitual interpretation makes some hypothetically unaccusative verbs permissible in the impersonal -no/-to construction." See Ruda (2014: 208-209) for additional discussion. 
Recall Oesterreicher's (1926) observation that the new Polish passive-like construction became productive with an accusative object only upon the disappearance of the auxiliary, otherwise obligatory in the Polish passive. We can assume a period of time before the complete isolation and subsequent reanalysis of old neuter singular /-o/ during which this form, when attached to passive morphology, was ambiguous between an agreeing canonical passive and the new impersonal expression (recall the discussion surrounding examples (3) and (4)). The ambiguity lay not only in the analysis of /-o/, but in the case marking of neuter singular objects, which, recall, are syncretic for nominative and accusative. The next step was for objects with distinct nominative and accusative forms to be marked accusative unambiguously, as in (16), from the $16^{\text {th }}$ century:

(16) Old Polish

Przykazał, aby łodkę uczynio-no z rokiciny. he-ordered COMP boat-ACC made-PAss from wicker 'He ordered that a boat be made of wicker.' (Brajerski 1979: 91)

The example in (16) also illustrates the anomalous occurrence of passive verb forms without a tense-marking auxiliary, particularly here where the complementizer aby obligatorily occurred with a past auxiliary. Recall the evidence adduced above against treating/-no/-to/ as a Voice morpheme. The complementary distribution of /-no/-to/ with auxiliaries, coupled with the past-tense interpretation of this innovative structure, as indicated in the sentential glosses, suggests that /-no/-to/ in the modern language is itself an instantiation of Tense - the old passive morpheme has been reanalyzed as an auxiliary of sorts (cf. Lavine 2005). The analysis, then, for Polish is that the old passive morpheme has been grammaticalized via reanalysis from a position marking Voice within $v \mathrm{P}$ to the head of Tense, the projection immediately dominating $v \mathrm{P}$, where it bears the [+PAST] feature, but a defective set of agreement features. ${ }^{17}$ This is precisely the kind of reanalysis described by Roberts and Roussou 2003, as movement (over time) from one functional position to another, upwards along the hierarchy of functional projections. The analysis for Polish is schematized in (17); the dotted line indicates the diachronic movement of the old passive morpheme.

17 See Ruda 2014 for evidence that Tense in the Polish -no/-to construction bears the features [NUMBER] and [GENDER], but not [PERSON]. 
(17) Polish /-no/-to/: Voice > Tense

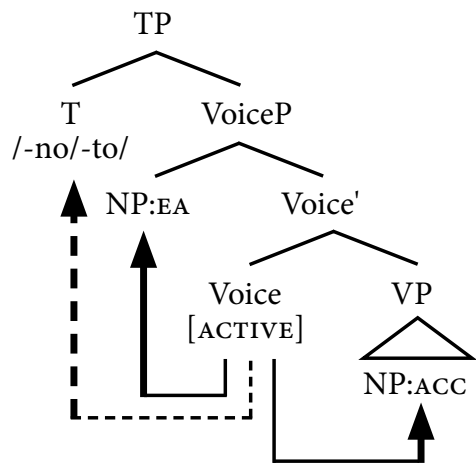

Treating /-no/-to/ as a Tense marker explains the full range of phenomena detailed above. First, and most important, it accounts for the active Voice setting, from which follows the ban on passive $b y$-phrases and the presence of a fully-thematic, syntactically active argument in Spec,VoiceP, as evidenced by the binding and control facts. Note additionally that since active Voice is necessarily (external-) argument-projecting, we now understand the incompatibility of the Polish construction with unaccusatives, which lack an external argument. Finally, removing old passive /-no/-to/ from Voice renders the survival of accusative in this passive-like structure unexceptional.

The auxiliariless structure is a hallmark feature of the innovative construction. The early borrowings of the impersonal construction in Ukrainian likewise appeared without tense-marking auxiliaries, as in (18-19):

(18) Middle Ukrainian

Pavlusja u Varšavi stja-to.

Pavlus'-ACC in Warsaw beheaded-PAss

'Pavlus was beheaded in Warsaw.'

(19) Middle Ukrainian

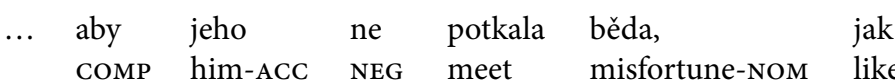

Stefana popa, kotoroho $\mathrm{v}$ Luc'kij rěcě utople-no.

Stefan priest-ACC whom-ACC in Luc'k river drowned-PAss

'So that he were not met with misfortune like Stefan the priest, who was drowned in the Lutsk River.' (Borkovskij 1968: 178)

Indeed, the auxiliariless structure continued into the modern period, as documented in Petlyčnyj's (1960) study of the language of the late-19 $9^{\text {th }}$ century Western Ukrainian writer Ivan Franko. Examples from his prose works are given in (20-21). 
(20) Ukrainian

S’hodni uv'jazne-no tut jakohos' Davyda Šternberga.

today imprisoned-Pass here some David Shternberg-ACC

'Today a certain David Shternberg was imprisoned here.' (Petlyčnyj 1960: 29)

(21) Ukrainian

Ja duže rad, ščo taku dražlyvu i važnu temu

I very glad that such sensitive and serious theme-ACC

obhovore-no tut tak spokijno.

discussed-PAss here so calmly

'I am very glad that such a delicate and serious matter was discussed here so calmly'.

(Petlyčnyj 1960: 28)

While Ukrainian prescriptivists sought to maintain the Polish pattern, mainly in response to perceived linguistic incursions from the East (see Shevelov 1963: 142146, 1989), we will see in Section 3.3 that the auxiliariless structure was unmotivated in the Ukrainian construction and not continued in the spoken language.

Before turning to Ukrainian, let us briefly consider one piece of evidence in favor of the "bundled" $v \mathrm{P}$ structure given for Polish in (17). The bundled structure, in which the features of Voice and Cause occur on a single $v$-head, is indicated by the inability of Cause, the source of accusative, to operate independently of the setting for Voice. This is what rules out Polish sentences of the type previewed in (2a), repeated below in (22a). The sun, as a Natural Force, is incompatible with the requirement that Polish -no/-to occur with a PROARB subject of Voice (but see fn. 4). The Ukrainian counterpart, given in (2b) and below in (22b), is perfectly grammatical. In the case of Ukrainian, but not Polish, a non-agentive, internal argument can activate Cause independently. ${ }^{18}$

(22) a. Polish ${ }^{19}$

*Drzewo spalo-no słońcem.

wood-ACC burned-PAss sun-INS

[Intended: 'The wood was burned by the sun.']

b. Ukrainian

Derevo bulo vypale-no soncem.

wood-ACC AUX-PST burned-PAss sun-INS

'The wood was burned/warped by the sun.'

${ }^{18}$ In Ukrainian, then, $v \mathrm{P}$ is crucially specified as unbundled.

${ }^{19}$ One may wonder whether a passive counterpart of $(2 a) /(22 a)$ is grammatical. On the reading in which there is no underlying external argument, a genuine passive should be ruled out (regardless of whether the features of $v$ are bundled). Thus, (i) is best treated as a stative, adjectival passive, in which case słońcem 'sun-INs' is not a by-phrase, but rather an internal argument, denoting Natural Force (see Grimshaw 1990: 124-129 for related discussion on adjectival passives).

(i) Drzewo było spalo-ne słońcem.

wood-NOM.N.sG AUX-PST.N.sG burned-N.sG sun-INS

'The wood was burned/warped by the sun.' 
Consider now the interpretation of (23). Since Cause does not occur independently in the Polish construction and active Voice is obligatorily argument-projecting, the only possible interpretation is that given in (23a), and not (23b):

(23) Polish

Wybi-to szybę.

broken-PAss window-pane-ACC

a. 'Someone/some people broke the window pane.'

b. “'The wind/storm broke the window pane.'

As predicted, the interpretation in (23b) is available in Ukrainian, along the pattern of (22b), illustrating a crucial difference in the shape of $\nu \mathrm{P}$ across the two languages: Cause functions independently of Voice only in the Ukrainian construction. Thus, Ukrainian (24) is interpreted with non-active Voice on the reading in which there is no external argument.

(24) Ukrainian

Šybku bulo $\quad$ rozby-to.
window-pane-ACC AUX-PST
'The window pane was broken (by the wind/storm).'

Note, however, that (24) is ungrammatical on an inchoative reading, in which the pane broke spontaneously. Accusative is available on the object only in case of an assumed second internal object (such as a Natural Force or Instrument) with causative semantics. Otherwise, Cause receives no interpretation and, it follows, there is no source for accusative (see Section 3.4 for further discussion).

To summarize, the Polish impersonal construction involves no valency-reducing operation - it is active. The presence of a null agentive subject explains the ungrammaticality of a $b y$-phrase and the predicate's incompatibility with unaccusative verbs. The lack of a tense-marking auxiliary and persistence of the old neuter singular /-o/ further removes the impersonal form from the passive paradigm. The "therapy" performed on the grammar to bring these properties in line, particularly in the presence of accusative marking on the object, involved the removal of erstwhile /-no/-to/ from its position within $v \mathrm{P}$ and its reanalysis as a Tense marker. An ambiguous surface syntactic arrangement was thereby made regular by means of the assignment of a new syntactic category to the old passive morpheme.

\subsection{Ukrainian: Elaboration of $v \mathrm{P}$}

According to Shevelov $(1968,1969)$, Ukrainian is assumed to have "borrowed" the impersonal construction from Polish, a fact supported by intense linguistic 
contact precisely during the period when the construction developed..$^{20}$ The development in Ukrainian of an innovative, non-agreeing form was supported by the purely phonological development leading to the same isolated neuter singular form in /-o/, as discussed in Section 2. The analysis advanced for Polish - namely, reanalysis of the Voice morpheme as a Tense head - is patently inappropriate for Ukrainian in light of the facts given in (25-26). The example in (25) indicates a non-active (passive) Voice head, which participates in the licensing of a passive $b y$-phrase, marked in Ukrainian by a bare instrumental NP. The example in (26) indicate unaccusative Voice - there is no material, implicit or otherwise, in the Spec,VoiceP position. ${ }^{21}$ Finally, note that (25) illustrates the non-complementarity of the Ukrainian /-no/-to/ morpheme with tense-marking auxiliaries.

(25) Ukrainian: Passive by-phrase

Tabir bulo zajnja-to amerykans'kym vijs'kom.

camp-ACC AUX-PST occupied-PASs American troops-INS

'The camp was occupied by American troops.' (Wieczorek 1989: 117)

(26) Ukrainian: Non-Agentive Cause

Bereh rozmy-to tečijeju.

shore-ACC washed-away-PAss current-INS

'The shore was washed away due to the current.' (Parxomenko 1956: 315)

The co-occurrence of passive-participial morphology on the verb and accusative on the object NP was handled in Polish by positing that the old passive morpheme underwent a change in category to a position no longer involved in argument realization and case possibilities. After Ukrainian adopted the surface syntax of the new Polish impersonal, while initially resisting the use of overt auxiliaries, potentially allowing for the same kind of category change for /-no/-to/, the construction eventually began to show signs of a different direction of grammaticalization, one that accommodated the persistent passive status of /-no/-to/, replete with by-phrases and Tense auxiliaries, while still admitting accusative objects. As the Ukrainian construction diverged from its Polish counterpart, a new strategy had to be devised by speakers of Ukrainian to accommodate the surface syntactic arrangement. ${ }^{22}$ On the bundled- $v \mathrm{P}$

${ }^{20}$ Ukraine was under Polish and Lithuanian domination since the latter part of the $14^{\text {th }}$ century, first under the Grand Duchy (Principality) of Lithuania and then under the PolishLithuanian Commonwealth, where Ukrainian lands were exclusively under Polish control. It wasn't until the partitions of Poland in the late $18^{\text {th }}$ century that most of Ukraine came under Russian influence.

${ }^{21}$ It follows that tečijeju 'current-ins' is not a passive by-phrases, but rather a VP-internal argument, case-marked as instrumental by virtue of its semantic function of Natural Force.

${ }^{22}$ See Shevelov (1963: 142-146) on the dispute among Ukrainian linguists in the early part of the $20^{\text {th }}$ century over how to evaluate modern usage of the impersonal passive as it diverged from the Polish pattern. 
structure, now familiar from Polish, Voice is responsible for accusative since it contains the [CAUSE] feature in one complex head. Note, however, that a bundled $v \mathrm{P}$ would fail to assign accusative in the passive Ukrainian construction. ${ }^{23}$ For /-no/-to/ to remain passive in Ukrainian while preserving accusative on the object, the $v \mathrm{P}$ would require further elaboration. An innovative structure was now necessary to tease apart the predicate's Voice property from its transitivity property. Only in this way could accusative now appear on the object regardless of the predicate's setting for passive Voice. Recall that this is achieved only on the "unbundled" or split- $v$ P structure.

To be sure, both languages created new grammatical structures to accommodate anomalous surface syntax (i.e., passive cum accusative). In the case of Ukrainian, this new grammatical structure is expressed in $v \mathrm{P}$ by the creation of two discrete $v$-heads from the [VOICE] and [CAUSE] features that we assume were combined in a single $v$-head in an earlier stage of the language, prior to the emergence of the passive-plus-accusative construction. The structural change posited here is illustrated in (27):

(27) Ukrainian /-no/-to/: Voice > Voice + Cause

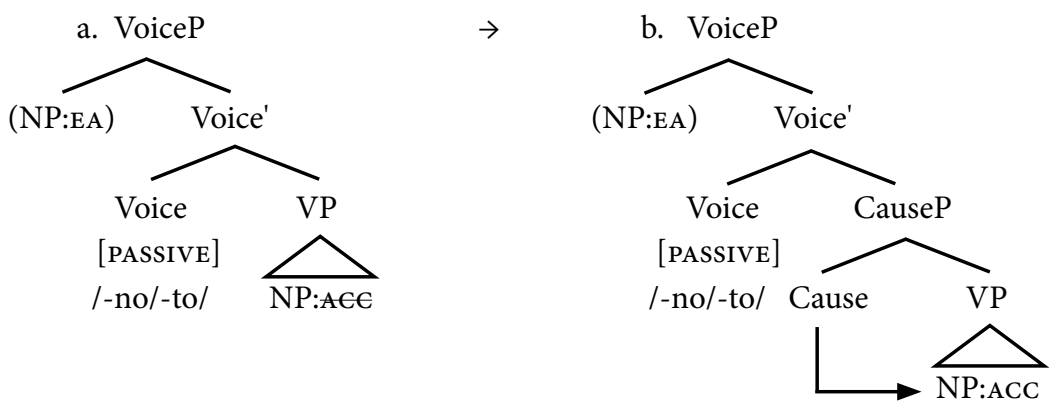

In (27a), the passive Voice head is intransitive (accusative is unavailable). Recall the crucial difference between the pre-grammaticalized structure in (27a) and Polish (17): in Polish, /-no/-to/ no longer heads Voice, thus accusative assignment is not suppressed, as it is in the case of canonical passives. In contrast, note how accusative assignment persists in the grammaticalized split- $v \mathrm{P}$ in (27b). While the passive morpheme still heads Voice, there is no suppression of accusative by virtue of Cause occurring independently. Note additionally that the interpretation of the Ukrainian construction is not always passive. The reading is passive only when Voice is responsible for the projection of an implicit subject in its specifier (NP:EA). Although the implicit subject does not

${ }^{23}$ In the case of the bundled $\nu \mathrm{P}$, passive /-no/-to/ structurally dominates Cause, suppressing its transitivity property. This is the standard arrangement for the passive, e.g., in English, in which the passive detransitivizes. 
bind or control, as we saw in Section 3.2, its presence licenses the passive byphrase (25) and is further suggested by the occurrence of Agent-oriented adjunct phrases, as in (28):

(28) Ukrainian: Agent-Oriented Adjunct

Inozemcja bulo posadže-no do v'jaznyci, ščob izoluvaty joho foreigner-ACC AUX-PST placed-PASS to prison in-order to isolate him-ACC 'A foreigner was placed in prison in order to isolate him.'

The Ukrainian impersonal, however, also occurs in the absence of any implicit external agency as a non-passive, as in the example in (29) (in addition to (26)):

(29) Ukrainian

Vysnažene oblyččja joho bulo zvernu-to do travnevoho neba. exhausted face-ACC his AUX-PST turned-PAss to May sky

'His exhausted face was turned to the May sky.' (Shevelov 1963:141)

It is precisely in these cases that Cause functions independently, since the passive morpheme in the absence of an external argument, as in (29), indicates merely non-active Voice.

\subsection{On Cause}

For accusative to occur, regardless of the structure of $v P$, the [CAUSE] feature has to be "identified" in some way. In event-decompositional syntax (see, esp. Borer 2005), Cause functions much like an unsaturated predicate. It requires saturation (valuation) for the causative sub-event to enter the semantics, thereby setting in motion the corresponding syntactic reflex of accusative assignment. But rather than projecting its own argument, it merely requires the presence of some other argument with the right (causative) semantics (much like the Asp-head in Borer 2005). In the case of the Polish impersonal, where Cause is folded into Voice, Cause receives its value from the PRO-ARB subject. In the event that the Ukrainian impersonal is passive, Cause is likewise valued by the implicit subject in Spec,VoiceP (see Baker and Vinokurova 2010 for a similar implicit subject effect in Sakha).

It now remains to provide further justification of the Cause head itself. What if, for example, Cause receives no value? It follows that the structure should not appear licitly with accusative. Consider again (24), repeated below as (30). There are three plausible interpretations of this sentence, given in $(\mathrm{a}-\mathrm{c})$, only two of which are licit:

(30) Ukrainian

Šybku bulo rozby-to.

Window pane-ACC AUX-PST broken-PASS

a. 'The window pane was broken (by the thieves).'

b. 'The window pane was broken (by the wind/storm)'

c. *'The window pane broke (spontaneously)' 
In the passive in (30a), Cause is valued by the implicit Agent, which optionally appears as a $b y$-phrase. Now compare (30b-c). (30b) is crucially a causative structure - Cause is valued by an understood Natural Force argument (wind, storm, ...). In the absence of this second internal argument, that is, on the inchoative (anticausative) reading in (30c), Cause remains unvalued and the sentence is ungrammatical with accusative. It follows that the Natural Force causer construction in (30b) is necessarily dyadic and causative: a second, internal, non-Theme argument with the right semantics must be projected (even if not pronounced) in order to provide a value for Cause.

Other predicate types in which Cause fails to be valued include basic (monadic) unaccusatives, Experiencer predicates, and stative adjectival predicates, none of which occur with accusative in the Ukrainian impersonal construction. Each of these predicate types is taken up in turn. The point is to demonstrate that an independently-functioning Cause head is a necessary component of the innovative Ukrainian structure.

Note first the examples in (31), which differ minimally as to whether the predicate is dyadic or monadic. ${ }^{24}$

(31) Ukrainian

\begin{tabular}{|c|c|c|c|}
\hline a. Dyadic & & & \\
\hline Xatu & bulo & spale-no & blyskavkoju. \\
\hline house-ACC & AUX-PST & burned-down-pAss & lightning-INS \\
\hline 'The house & as burned & own by a strike of lig & tning.' \\
\hline b. Monadic & & & \\
\hline${ }^{\star}$ Xatu & bulo & zhore-no. & \\
\hline house-ACC & AUX-PST & burned-down-PAss. & NTICAUS \\
\hline [Intended: & he house $b$ & ned down.'] & \\
\hline
\end{tabular}

The anticausative (ANTICAUS) in the (b) sentences denotes events that are insufficiently complex to appear with accusative. Since there is no causative subevent asserted, the Cause head is not activated and accusative is not licensed.

The Cause head is likewise not activated in the case of Experiencer predicates when occurring in the impersonal construction. It has been widely observed that in the case of Experiencer predicates, the non-Experiencer argument varies between a high "causative" reading and a low reading as Stimulus

${ }^{24}$ In the absence of a causer, as in (31b), the underlying Theme appears in the nominative in a stative adjectival construction, as in (i) (see also (34)):

(i) Katuška bula zhore-na i čerez to neznaju čy coil-NOM.F.SG AUX-PST.F.SG burned-F.SG and due-to that I-don't-know if robyt' provodka. works wiring-NOM 'The coil was burned out [when I bought the car] so I don't know if the wiring works.' (auto.ria.ua; 24.10.2012) 
of the mental state denoted by the verb (Pesetsky 1995; Arad 1998; McGinnis 2000; Folli and Harley 2007). Since the high causative reading is associated with the subject position, which is not projected in the impersonal, the Experiencer predicate tests whether Cause, as a result, fails to receive a value. ${ }^{25}$ As predicted, the Stimulus reading on the non-Experiencer argument, as the "subject matter" of the mental state denoted by the verb, rather than its cause, is insufficient to activate the Cause head. It follows that Experiencer predicates in the impersonal construction are degraded with accusative, as indicated in (32a-b):

(32) Ukrainian: Impersonal Experiencer Predicate
* Ivana
bulo
zdyvova-no
blyskavkoju.
Ivan-ACC AUX-PST surprised-PAss lightning-INS
[Intended: 'Ivan was surprised by/at the lightning.']
b. ${ }^{\star I v a n a}$ bulo vtiše-no ihraškoju.
Ivan-ACC AUX-PST consoled-PAss toy-INS
[Intended: 'Ivan was consoled by the toy.]

Note that ungrammatical (32a) and grammatical (31a) differ only with respect to the semantics of blyskavkoju 'lightning-Ins'. While in (31a) lightning is the cause of the burning-down event, in (32a) lightning is merely the target of the state of surprise - what Ivan is surprised at.

The connection between causation and accusative is further revealed in the stative adjectival predicate in $(33 a-b)$ :

(33) Ukrainian: Stative Adjectival Predicate

a. ${ }^{*}$ Osnovne značennja slova
basic zoseredže-no $\quad \mathrm{V}$ koreni.
[Intended: 'The basic meaning of the word is concentrated in its root.']
b. ${ }^{*}$ Našu hazetu
our newspaper-ACC closely connected-PAss with readers
[Intended: 'Our newspaper is closely connected with its readers.']
(Shevelov 1963: 142)

The examples in (33) are degraded because there is no person (Voice) or natural force (Cause) that can concentrate the meaning of a word in its root or physically connect a newspaper to its readers. Compare (33a-b) with their nominative, agreeing counterparts in $(34 a-b)$ :

${ }^{25}$ See Lavine 2010b for a fuller account of the incompatibility of Experiencer predicates with Russian and Ukrainian impersonals. As expected, in the personal variant of (32a), given below in (i), the non-Experiencer argument receives the Causer-Stimulus reading as subject, thereby identifying Cause as active, and licensing accusative case:
(i) Blyskavka
zdyvuvala
Ivana
lightning-NOM.F.SG surprised-F.SG
Ivan-ACC
'Lightning surprised Ivan.' 
(34) Ukrainian: Agreeing Adjectival Participles

$\begin{array}{clllll}\begin{array}{c}\text { a.Osnovne } \\ \text { basic }\end{array} & \text { meaning-NOM.N.sG } & \text { of-word } & \text { concentrated-N.sG } & \text { in root } \\ \text { b. Naša } & \text { hazeta } & \text { tisno } & \text { zvjaza-na } & \mathrm{z} & \text { čytačamy. } \\ \text { our } & \text { newspaper-NOM.F.sG } & \text { closely } & \text { connected-F.SG } & \text { with } & \text { readers }\end{array}$

To summarize, an independent Cause head in Ukrainian is responsible for the co-occurrence of accusative and passive morphology. Basic (monadic) unaccusatives, Experiencer predicates, and statives fail to occur with accusative in the impersonal construction due to a lack of causation. It follows that Cause in the Ukrainian construction is syntactically active as an independent head in a split- $v$ P. The /-no/-to/ morpheme in Ukrainian is merged under Voice, marking it as non-active (passive or unaccusative).

\section{Conclusion}

The reanalysis that gave rise to new impersonal constructions in Polish and Ukrainian was provoked by morphological change. Forms in /-no/-to/ were ambiguous for some time between an older passive, agreeing for neuter singular, and an innovative impersonal construction that occurred with accusative objects. In Polish, the innovative structure coincided in time with the suppression of tense-marking auxiliaries and an active, rather than passive, interpretation, suggesting an analysis in which /-o/, combined with passive /-n-/-t-/, ceased to be interpreted as relevant to the voice system of the language, but rather came to be interpreted as a marker of Tense. A close account of the modern distribution of the construction in the two languages indicates that erstwhile passive/-no/to/ was grammaticalized along two different paths. While the Ukrainian construction, in some cases right up to the late $19^{\text {th }}$ century, appeared faithful to its Polish source - particularly in appearing without an auxiliary - in the end, the innovative syntax in Polish was not borrowed intact. Crucially, /-no/-to/ persisted in its passive function in Ukrainian. In order to accommodate the passive cum accusative syntax, the language developed an elaborated $\nu \mathrm{P}$, with the purpose of teasing apart features related to voice from the predicate's transitivity property. Accusative now came to appear in the impersonal construction with Natural Force causers as an extension of this structural innovation.

More generally, this paper adduces evidence from diachronic data in support of a particular arrangement of features within $v$ P. While much recent work has addressed the consequences of variation in the shape of $v \mathrm{P}$ for synchronic comparative purposes, it is evident that the same range of variation can be applied to change within the history of a single language. In this way, the study of syntactic change serves as another source of evidence for the kinds of structures that occur and for the consequences of microvariation across these structures. 


\section{References}

Adams Alla Nedashkivska (1998). Transitivity, Pragmatics, and Discourse in the Morphosyntax of Contemporary Ukrainian. PhD dissertation, University of Pittsburgh.

ArAd Maya (1998). VP-Structure and the Syntax-Lexicon Interface. PhD dissertation, University College London.

BAILYN John (1998). Syntactic theory and the history of the Slavic languages. In American Contributions to the Twelfth International Congress of Slavists. Robert A. Maguire, Alan Timberlake (eds.), 250-270. Bloomington, IN: Slavica.

BAKER Mark et al. (1989). Passive arguments raised. Linguistic Inquiry 20, 219-251.

BAKer Mark, Vinokurova Nadya (2010). Two modalities of case assignment: case in Sakha. Natural Language and Linguistic Theory 28, 593-642.

Bevzenko S.P. (1960). Istoryčna morfolohija ukrains'koji movy. Užhorod: Zakarpats'ke Oblasne Vydavnyctvo.

Borer Hagit (1994). The projection of arguments. In Functional Projections. Elena Benedicto, Jeffrey Runner (eds.), 19-47. Amherst, MA.: University of Massachusetts Occasional Papers 17.

Borer Hagit (2005). Structuring Sense: The Normal Course of Events. New York: Oxford University Press.

Borkovskij V.I. (1968). Sravnitel’no-istoričeskij sintaksis vostočnoslavjanskix jazykov: Tipy prostogo predloženija. Moskva: Nauka.

Bowers John (2002). Transitivity. Linguistic Inquiry 33, 183-224.

Brajerski Tadeusz (1979). Geneza orzeczeń typu (z)jedzono i (vy)pito. Język Polski 59, 84-98.

BRUENING Benjamin (2013). By phrases in passives and nominals. Syntax 16, 1-41.

Cetnarowska Bożena (2000). The unergative/unaccusative split and the derivation of resultative adjectives in Polish. Formal Approaches to Slavic Linguistics 8, 78-96.

Сномкку Noam (1995). The Minimalist Program. Cambridge, MA: MIT Press.

Collins Chris (2005). A smuggling approach to the passive in English. Syntax 8, 81120.

DyŁA Stefan (1983). Some further evidence against an impersonal passive analysis of Polish impersonal constructions. Studia Anglica Posnaniensia 15, 123-128.

Dziwirek Katarzyna (1994). Polish Subjects. New York: Garland.

Foldi Raffaella, HARLEY Heidi (2007). Causation, obligation, and argument structure: On the nature of little $v$. Linguistic Inquiry 38, 197-238.

Grimshaw Jane (1990). Argument Structure. Cambridge, MA: MIT Press.

Kibort Anna (2001). Morpholexical rules in Polish revisited. In Generative Linguistics in Poland: Syntax and Morphology. Adam Przepiórkowski, Piotr BAŃski (eds.), 101-114. Warszawa: Instytut Podstaw Informatyki Polskiej Akademii Nauk.

KIBORT Anna (2008). Impersonals in Polish: an LFG perspective. Transactions of the Philological Society 106, 246-289.

KLemensiewicz Zenon et al. (1965). Gramatyka historyczna języka polskiego. Warszawa: Państwowe Wydawnictwo Naukowe.

Kratzer Angelika (1996). Severing the external argument from its verb. In Phrase Structure and the Lexicon. Johan Rooryck, Laurie Zaring (eds.), 109-137. Dordrecht: Kluwer. 
KrZEK Małgorzata (2013). Interpretation and voice in Polish SIE and -NO/-TO constructions. In Current Issues in Slavic Linguistics. Irina Kor CHAHINE (ed.), 185197. Amsterdam: John Benjamins.

Lavine James (2005). The morphosyntax of Polish and Ukrainian -no/-to. Journal of Slavic Linguistics 13, 75-117.

LAVine James (2010a). Case and events in transitive impersonals. Journal of Slavic Linguistics 18, 101-130.

LAvine James (2010b). Case and events in Ukrainian Experiencer Predicates. Formal Approaches to Slavic Linguistics 18, 284-300.

LAvine James (2013). Passives and near-passives in Balto-Slavic: On the survival of accusative. In Non-canonical Passives, Artemis Alexiadou, Florian SchäFER (eds.), 185-211. Amsterdam: John Benjamins.

LEgate Julie Anne (2014). Voice and v: Lessons from Acehnese. Cambridge, MA: MIT Press.

Lightfoot David (1979). Principles of Diachronic Syntax. Cambridge: Cambridge University Press.

Lightғоот David (1991). How to Set Parameters: Arguments from Language Change. Cambridge, MA: MIT Press.

MaLING Joan (1993). Unpassives of unaccusatives. Ms., Brandeis University.

MALING Joan, SigurJónsdótTir Sigríđur (2002). The 'New Impersonal' construction in Icelandic. Journal of Comparative Germanic Linguistics 5, 97-142.

McGinnis Martha (2000). Event heads and the distribution of psych-roots. In University of Pennsylvania WPL 6. Alexander Williams, Elsi KaISER (eds.), 107-44. Philadelphia: University of Pennsylvania, Department of Linguistics.

Oesterreicher Henryk (1926). Imiesłów bierny w języku polskim. Kraków: Polska Akademia Umiejętności.

PARXomenko O.M. (1956). Ukrajins'ka mova, častyna 1. Kyjiv: Radjans'ka škola.

Pesetsky David (1995). Zero Syntax. Cambridge, Mass.: MIT Press.

Petlyčny I.Z. (1960). Bezosobovi rečennja na $-N O$, -TO v movi xudožnoji prozy I. Franka. Pytannja ukrains'koho movoznavstva 4a, 21-37.

PIsArkowa Krystyna (1984). Historia składni języka polskiego. Wrocław: Polska Akademia Nauk.

Pylkkänen Liina (2008). Introducing Arguments. Cambridge, MA: MIT Press.

Roberts Ian, Roussou Anna (2003). Syntactic Change: A Minimalist Approach to Grammaticalization. Cambridge: Cambridge University Press.

Rozwadowska Bożena (1992). Thematic Constraints on Selected Constructions in English and Polish. Wrocław: Wydawnictwo Uniwersytetu Wrocławskiego.

RudA Marta (2014). The impersonal subject $-n /-t$ construction in Polish and the typology of voice heads. Studies in Polish Linguistics 9, 203-243.

SHEvelov George (1963). The Syntax of Modern Literary Ukrainian. The Hague: Mouton.

SHevelov George (1968). Orzeczenia bezpodmiotowe odimiesłowowe na -no/-to w języku polskim przed rokiem 1450. Slavia Orientalis 17, 387-393.

SHEvELOV George (1969). The vicissitudes of a syntactic construction in Eastern Slavic. Scando-Slavia 15, 171-186.

Shevelov George (1979). A Historical Phonology of the Ukrainian Language. Heidelberg: Carl Winter. 
Shevelov George (1989). The Ukrainian Language in the First Half of the Twentieth Century (1900-1941): Its State and Status. Cambridge, MA: Harvard Ukrainian Research Institute.

Siewierska Anna (1988). The passive in Slavic. In Passive and Voice, Masayoshi Shibatani (ed.), 243-289. Amsterdam: John Benjamins.

SigurĐsson Halldór (2003). Case: abstract vs. morphological. In New Perspectives on Case Theory. Ellen Brandner, Heike ZinZmeister (eds.), 223-268. Stanford: CSLI.

SPRINČAK Ja.A. (1960). Očerk russkogo istoričeskogo sintaksisa: prostoe predloženie. Kiev: Radjans'ka škola.

ŚPIEWAK Grzegorz, Szymańska Izabela (1997). Polish impersonal constructions: an exercise in head formation and argument licensing. In Formale Slavistik, Uwe JUNGhanns, Gerhild Zyвatow (eds.), 145-154. Frankfurt am Main: Vervuert Verlag.

van Hout Angeliek (2000). Event semantics in the lexicon-syntax interface. In Events as Grammatical Objects. Carol Tenny, James Pustejovsky (eds.), 239-282. Stanford: CSLI.

van Hout Angeliek (2004). Unaccusativity as telicity checking. In The Unaccusativity Puzzle. Artemis Alexiadou et al. (eds.), 60-83. Oxford: Oxford University Press.

Wieczorek Diana (1987). Formy na -no, -to z instrumentalis agentis (subiecti) we współczesnej ukraińszczyźnie. Slavia Orientalis 36, 551-559.

Wieczorek Diana (1989). Konstrukcii tipa mnoju oderžano lysta v sovremennom ukrainskom jazyke. In $Z$ problemów ewolucji współczesnych języków słowiańskich w aspekcie socjolingwistycznym. Albert BARTOszeWICz (ed.), 113-118. Warszawa: Wydawnictwo Uniwersytetu Warszawskiego.

WieCzOREK Diana (1994). Ukrainskij pierfiekt na -NO, -TO na fonie polskogo pierfiekta. Wrocław: Wydawnictwo Uniwersytetu Wrocławskiego.

WiEmer Björn (to appear). On the rise, establishment and continued development of subject impersonals in Polish, East Slavic and Baltic. In Diachronic Typology of Voice and Valency-Changing Categories. Seppo Kittilë, Leonid Kulikov (eds.), Amsterdam: John Benjamins.

Woolford Ellen (2003). Burzio's Generalization and markedness. In New Perspectives on Case Theory. Ellen Brandner, Heike Zinzmeister (eds.), 301-329. Stanford: CSLI.

\author{
Linguistics Program \\ 172 Coleman Hall \\ Lewisburg, Pennsylvania 17837 USA \\ [jlavine(at)bucknell.edu]
}

